ISSN1027-5495. Functional Materials, 24, No.2 (2017), p. 261-263

doi:https://doi.org/10.15407/fm24.02.261

(C) 2017 - STC "Institute for Single Crystals"

\title{
The analysis of the defects on the surface of galvanized steel structures
}

\author{
Lie-long Wang, Liang-liang Zhou \\ School of Mechanical and Electrical Engineering, Chizhou University, \\ Anhui, Chizhou, 247000, China
}

Received January 25,2017

\begin{abstract}
Some black spots were found on the surface GA products, which could not meet the requirements of production of outside panel of automobile. The cause of the defects was investigated. Methods of their elimination are suggested.
\end{abstract}

Keywords: Hot dip galvanization, alloy treatment, defec, SEM, EPMA

На поверхности оцинкованной (ГА) продукции обнаружены черные пятна, которые не могут отвечать требованиям производства наружной панели автомобиля. Исследована причина дефектов. Предложены методы их устранения.

Аналіз дефектів на поверхні оцинкованих сталевих конструкцій. Лi-Лун Ван, Лян-Лян Чжоу

На поверхні оцинкованої (ГА) продукції виявлені чорні плями, які не можуть відповідати вимогам виробництва зовнішньої панелі автомобіля. Досліджено причина дефектів. Запропоновано методи їх усунення.

\section{Introduction}

GA products due to electrochemical protective effect of zinc coating on the surface of the steel substrate, has good corrosion resistance[1-3]. and substrate diversification and can guarantee GA products meet the requirements of all aspects such as: high strength steel, microalloyed steel, IF steel, bake hardening steel[4-9]. in addition, compared with galvanized products. GA products cost is low, and the surface quality of galvanized products are gradually approaching, so the use of GA products continue to expand the share in the market is increasing.

Although the surface quality of GA products has reached a high level, but also in the production of abnormal defects, such as iron, small bright spots, so that the product can not meet the high requirements. And because many production equipments, the distance space is huge, it is difficult to form a source for investigation of micro defects, so this type of defect control key belonging to different units of high grade hot galvanizing unit of product quality competition.

Finding spots defects in the operation process of domestic hot galvanizing unit of a automobile outer panel production, through testing laboratory microscopic analysis and composition, cooperate with the investigation and analysis of plant site, determine the formation position and mechanism of defects, defects can be successfully eliminated. The analysis method has a certain degree of versatility, and I hope to have a certain reference value for the domestic hot galvanizing workers.

\section{Experiments}

The defect is dotted with black color. From the macroscopic surface, the point defects extend along the rolling direction, which indicates that the black material adhered to the steel plate and produced a certain degree of deformation(in Fig.1). 


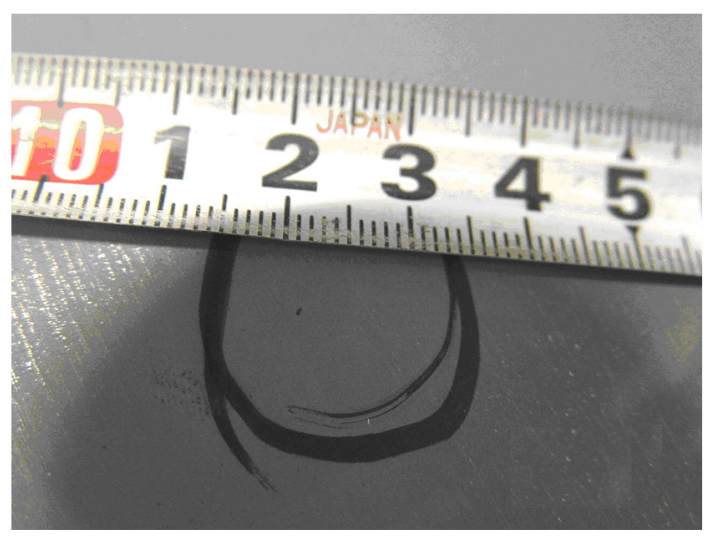

Fig. 1 Macro morphology of the black spot defects

SEM was used to observe the macroscopic morphology and the chemical composition was analyzed by EPMA. Alcohol was used to wipe the black defect, and the morphology of the defect area was observed and the chemical composition was analyzed.

\section{Results and Discussion}

Using SEM observation (in Fig 2), the surface of the defect has a rolling mark. The phenomenon of charge accumulation at the defect under the charge bombardment is shown.

EPMA analysis of the chemical composition of defects (in Fig 3), found that it is mainly composed of $\mathrm{C}, \mathrm{O}, \mathrm{Cl}$ and other elements, the chemical composition of rubber, the rest of the small amount of $\mathrm{Mg}, \mathrm{S}, \mathrm{Si}$ as the composition of rubber additives. Effect of $\mathrm{Zn}$ and $\mathrm{Fe}$ on the alloy galvanized sheet. Therefore, the black spot defect can be judged to be caused by the pressure of rubber particles.

In order to further judge the defect position in the production line, with alcohol will erase the rubber particles (in Fig 4), found that the defect area produces a pit, shows that the highly compacted role, and the surface electrical discharge texturing (roller printing machine working roller surface morphology after treatment with EDT).

Furthermore, the morphology of the region was observed by high magnification (in Fig 5), and no roll print was found on the SEM.

The composition analysis of the flaws removed area (in Fig 6), which mainly consisting of iron, zinc, quantitative analysis results: Fe $=10.2 \% ; \mathrm{Zn}=89.8 \%$, normal tissue zinc alloying layer, indicating the defects in normal after alloying annealing.

The strip is subjected to the greatest degree of deformation in the temper mill unit. The flattening machine extends the steel strip by applying the rolling force to form a uniform surface, and the surface roughness is given. After black

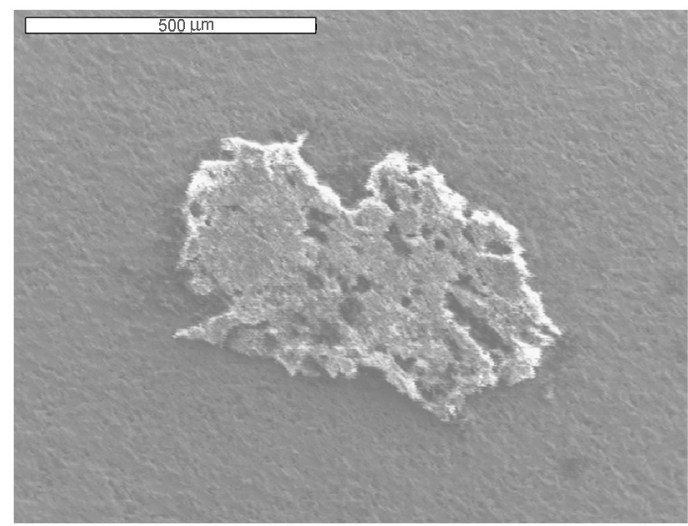

Fig. 2 The SEM observation of the black spot

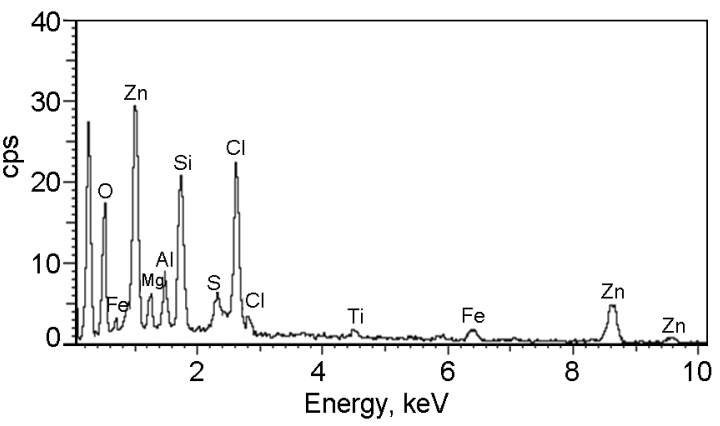

Fig. 3 The chemical composition of the black spot defect

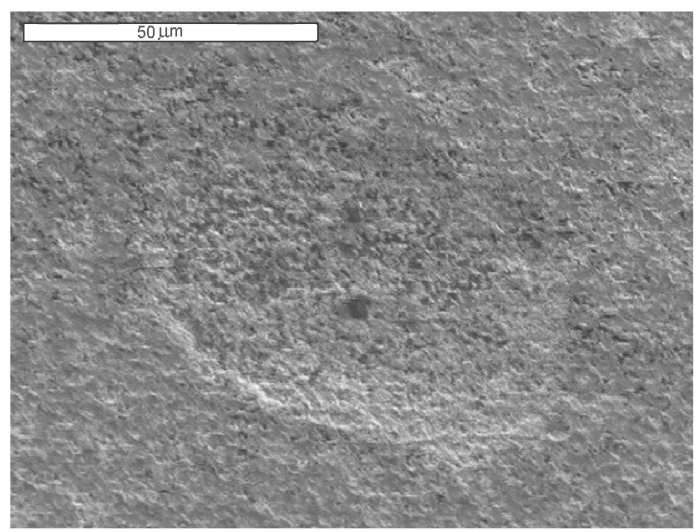

Fig. 4 The SEM morphology of the defect area after removing rubber powder using alcohol

foreign matter after the formation was rolled flat, on the flat machine with foreign texturing roller, foreign body erased, the following materials by foreign body shield, not smooth texturing roller, so that the black defects formed in the flat machine before.

Under the black foreign body, the zinc layer is intact, and the formation of the pit is the result of leveling. Chemical composition of zinc zinc layer after layer that normal alloy, galvanized strip after that and alloying, it adhered to the strip surface defects, after flattening machine, forming a certain extension, resulting in above defects. 


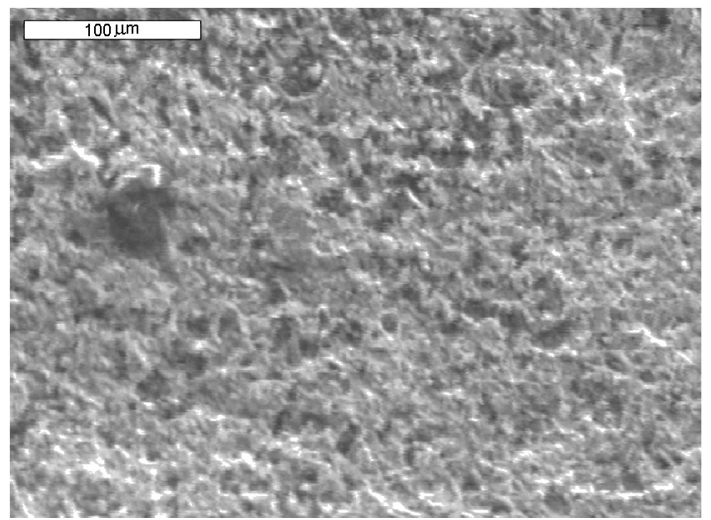

Fig. 5 The SEM observation of black spot area after removing rubber spot, and no skin level rolling marks were found.

The foreign body is an organic component, which indicates that the mechanical components of the defects are organic components.

For the hot dip galvanizing line, alloy after cooling section, the use of air cooling or spray cooling, followed by water, in order to prevent the surface water to the subsequent unit, squeezing, drying, and then enter the flat machine unit. In this process, air cooling and mist (fog) cooling; drying using hot air drying, these operations do not touch the strip without mechanical components. And after the water cooling roll. The organic components are used to ensure the roller surface to form a certain degree of deformation and improve the drying effect. Therefore, the cooling of the water after the formation of the black roller forming an important point of doubt. In order to avoid the pause of the unit, the dry roller is usually installed more than two groups, the normal production of a group of dry roll in standby state. The squeezing rollers are put into the open, and the spare input, the black spot defects disappeared, direct proof after cooling groove squeezing roll belongs to the defect source and the surface of the organic material shedding and adhesion to the strip surface, leads to black spot defect.

\section{Conclusions}

After the above analysis, the conclusion is as follows: 1) the black spot defects were the result of organic material is pressed into the strip; 2) organic matter on the alloying element and leveling unit; 3) the defect source for the cooling groove after squeezing roll of organic material, squeezing roll by switching, black spot defects disappeared; 4) the analysis of ideas can be applied to the treatment of hot dip galvanizing line of similar defects, quickly find the source of defects, to carry out operations adjustment, eliminate defects, improve the surface quality of hot dip galvanized products.

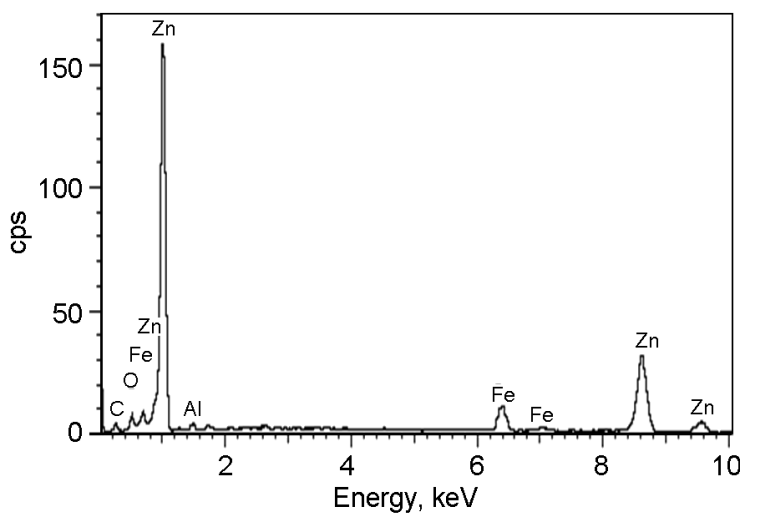

Fig. 6 The chemical composition of the black spot defect area after removing rubber powder, and the chemical elements includes ion and zinc, which is the normal composition of GA coating.

ACKNOWLEDGEMENT The work is financially supported by Provincial Science Foundation of Anhui (No. 1704a0902012).

\section{References}

1. Zhu L., Angang Techn., 36, 6, 58, 1999.

2. Q F Zhang, B J Liu, Steel Roll.,19, 33, 2002

3. Isobe Makoto T. Metal Finishing, 96(5), 97, 1998.

4. A.R. Marder, Prog. Mater. Sci., 45, 191, 2000

5. Li J, Yan Y H, Guo X H, et al. Adv. Mat. Res., 314-316, 2375, 2011,

6. He Y, Liu X, Guan C, et al. Int. Conf. Zinc and Zinc Alloy Coated Steel Sheet. 2013.

7. Xu Y. Process Research to Direct Hot Dip 55\%AIZn Process for Hot Rolled Pickling Strip[C]// 9th international conference on zinc and zinc alloy coated steel sheet 2 nd asi a-pacific galvanizing conference. 2013.

8. Yang H, Zhang S, Li J, et al. Surf.Coat.Techn., 240(3):269, 2013.

9. Longwei M A, Chen H. Comp.Aided Eng., ,2016. 